\title{
Evaluation of antibacterial activity of Laurus nobilis L., Rosmarinus officinalis L. and Ocimum basilicum L. from Northeast of Algeria
}

\author{
A. Ouibrahim ${ }^{1 *}$, Y. Tlili-Ait-kaki ${ }^{2}$, S. Bennadja ${ }^{2,3}$, S. Amrouni ${ }^{4}$, A. G. Djahoudi ${ }^{4}$ and \\ M. R. Djebar ${ }^{1}$
}

${ }^{1}$ Laboratory of Cellular Toxicology, Department of Biology, Faculty of Sciences, Badji Mokhtar University of Annaba, 23000, B.P. 12, Algeria.

${ }^{2}$ Laboratory of Medical Botany, Department of Pharmacy, Faculty of Medicine, Badji Mokhtar University of Annaba, 23000 , B.P. 12, Algeria.

${ }^{3}$ Laboratory of Biochemistry and environment Toxicology, Department of Biochemistry, Faculty of Sciences, Badji Mokhtar University of Annaba, 23000, B.P. 12, Algeria.

${ }^{4}$ Laboratory of Microbiology, Department of Pharmacy, Faculty of Medicine, Badji Mokhtar University of Annaba, 23000, B. P. 12, Algeria.

Accepted 25 June, 2013

\begin{abstract}
Rosmarinus officinalis L., Laurus nobilis L. and Ocimum basilicum L. are widespread herbs in Algeria. The essential oils of the three species were extracted from leaves by hydrodistillation. The yields were respectively $0.36,0.6$ and $0.71 \%$. The aim of this study was to evaluate the antibacterial activity of these essential oils against twenty bacterial strains: Enterococcus faecalis ATCC 29212, Staphylococcus aureus ATCC 25923, MRSA ATCC 31 (Méthicilino), Staphylococcus aureus, Staphylococcus epidermidis, Enterococcus avium, Escherichia coli ATCC 25922, Salmonella OMA 04, E. coli, Klebsiella oxytoca, Klebsiella pneumoniae, Proteus mirabilis, Enterobacter sp., Citrobacter freundii, Pseudomonas aeruginosa, Acinetobacter baumanii, Serratia marcescens, Salmonella sp., Shigella sp. and Providencia alcalifaciens. The essential oils were used in different concentrations. The diffusion tests on solid medium were efficient in all tested bacterial strains except Pseudomonas aeruginosa. The activity was more pronounced with the essential oil of Laurel. Indeed, the results of diffusion tests showed zones of inhibition as follows: Laurel, 8.4 to $22.4 \mathrm{~mm}$; Rosemary, 8.4 to $16.4 \mathrm{~mm}$ and Basil, 7 to $19.9 \mathrm{~mm}$. This study shows bacteriostatic effect of the three oils on all tested bacteria. The minimum inhibitory concentration (MIC) was determined by the dilution on solid medium method.
\end{abstract}

Key words: Rosmarinus officinalis L., Laurus nobilis L., Ocimum basilicum L., essential oils, antibacterial activity, minimum inhibitory concentration (MIC), Algeria.

\section{INTRODUCTION}

In recent years, multiple antibiotic resistances of pathogenic bacteria have been exacerbated by the excessive and inappropriate use of commercial antimicrobial drugs commonly used in the treatment of infectious diseases (Davis, 1994; Service, 1995). Renewed interest has grown in medicinal plants to counter resistance and find an alternative to antibiotics (Kalemba and Kunika, 2003; Juliani and Simson, 2002; 
Falerio et al, 2003).

Medicinal plants contain many phytochemicals composants such as flavonoids, alkaloids, tannins and essential oils. Among these plants, Rosmarinus officinalis, Ocimum basilicum and Laurus nobilis are widespread in the Mediterranean Basin (Quezel and Santa, 1963).

The three plants were harvested in El Kala National Park ranked Biosphere Reserve by UNESCO in 1990. Its area is $76,438 \mathrm{Ha}$ (Aouadi, 1989). It has a rich flora of about 850 species (De Belair, 1990) and characterized by a sub-humid Mediterranean climate.

Ocimum basilicum and Rosmarinus officinalis belong to Lamiaceae that include the most commonly used medicinal plants in the world as a spice and as a source of extract with strong antibacterial and antioxidant properties.

Rosemary is a shrub (Atik Bekkara et al., 2007), with 0.8 to $2 \mathrm{~m}$ height (Trujano-Gonzalez et al., 2007) and rich in essential oils (1 to $2.5 \%$ ). It has three chemotypes: cineol, camphor and verbenone (Santoyo et al., 2005; Graven et al., 1992); it contains also triterpene derivatives (2-4\%), flavonoids, tannins and saponins.

Basilicim Ocimum (Basil) is an aromatic plant (20 to 60 $\mathrm{cm}$ high), used as antispasmodic, aromatic, carminative, digestive, galactagogue, stomachic and tonic (Chiej, 1984; Lust, 1983; Duke and Ayensu, 1985). It contains 0.4 to $0.7 \%$ of essential oil, phenolic acids like rosamarinic acid, lithospermic acid $B$, vanillic acid, hydroxybenzoic acid, syringic acid, ferulic acid, protocatechuic acid, caffeic acid and gentisic acid, chicoric acid (Bais et al., 2002; Lee and Scagel, 2010); flavonoids and tannins (Grayer et al., 1996); cinnamic acid ester, triterpenoids and steroidal glycosides (Siddiqui et al., 2007).

Laurus nobilis belongs to Lauraceae. This aromatic tree is $2 \mathrm{~m}$ to $10 \mathrm{~m}$ high, it contains about $1.3 \%$ essential oils and polar flavonoids mono and sesquiterpenes (Novák, 1985; Appendino et al., 1992; Dall'Acqua et al., 2006), alkaloids (Kivçak and Mert, 2002), glycosylated flavornoids (Fiorini et al., 1998) and megastigmane and phenolic components (De Marino et al., 2004). It is known to have various pharmacological effects, including antimicrobial (Fraga, 2003), cytotoxic (Barla et al., 2007) and immune modulating (Park et al., 1996) activities.

The aim of this work was to evaluate the antibacterial activity of essential oils of these three plants against 20 bacterial strains: Enterococcus faecalis ATCC 29212, Staphylococcus aureus ATCC 25923, MRSAATCC 31 (Méthicilino), S. aureus, Staphylococcus epidermidis, Enterococcus avium, Escherichia coli ATCC 25922, Salmonella OMA 04, E. coli, Klebsiella oxytoca, Klebsiella pneumoniae, Proteus mirabilis, Enterobacter sp., Citrobacter freundii, Pseudomonas aeruginosa, Acinetobacter baumanii, Serratia marcescens, Salmonella sp., Shigella sp. and Providencia alcalifaciens.

\section{MATERIALS AND METHODS}

\section{Plant material}

The leaves of Laurus nobilis L., Rosmarinus officinalis L. and Ocimum basilicum L. were collected in April 2012 at El Kala National Park located at latitude $36^{\circ} 52^{\prime}$ north and longitude $8^{\circ} 27^{\prime}$ East. Laurel is spontaneous in the park; however, Basil and Rosemary are cultivated. The plants were dried in the shade in order to preserve the integrity of their molecules.

\section{Extraction of essential oils}

The extraction of essential oils was carried out by hydro-distillation using Likens Nickerson apparatus for $2 \mathrm{~h}$. We introduced $100 \mathrm{~g}$ of dry leaves in a flask filled with $3 / 4$ distilled water and then heated to boil. The water and oil are separated during the condensation of vapour loaded onto the oils (Chiej, 1984). Essential oils have been recovered in small opaque bottles and kept away from light, at a temperature of $4^{\circ} \mathrm{C}$. The yield was expressed in percentage.

\section{Evaluation of antibacterial activity}

\section{Bacterial strains}

The bacterial strains tested were provided by the Laboratory of Medical Microbiology, Faculty of Medicine Annaba. They are: Gram-positive Enterococcus faecalis ATCC 29212, Staphylococcus aureus ATCC 25923, MRSAATCC 31 (Méthicilino), Staphylococcus aureus, Staphylococcus epidermidis and Enterococcus avium.

Gram-negative Escherichia coli ATCC 25922, Pseudomonas aeruginosa ATCC 27853, Salmonella OMA 04, Escherichia coli, Klebsiella oxytoca, Klebsiella pneumoniae, Proteus mirabilis, Enterobacter sp, Citrobacter Freundii, Pseudomonas aeruginosa, Acinetobacter baumannii, Serratia marcescens, Salmonella sp, Shigella sp Providencia alcalifaciens. The bacterial strains were maintained and grown in a nutrient agar medium.

\section{Disk diffusion method}

The antibacterial activity was tested using the disk diffusion method (Davis, 1994). Bacterial cultures were reactivated by sub culturing on nutrient agar and incubated for $24 \mathrm{~h}$ at $37^{\circ} \mathrm{C}$. From these, pure cultures were prepared by releasing bacterial inoculum strains in physiological water. The homogeneous suspension was equivalent to $0.5 \mathrm{Mc}$ Farland, so an OD of 0.08 to 0.10 was read at $625 \mathrm{~nm}$.

Each essential oil was used at different concentrations: pure oil, diluted oil in DMSO (Dimethyl sulfoxide) to ratio 1/2, 1/4 and 1/8. Discs of $6 \mathrm{~mm}$ in diameter, previously sterilized, were used. $10 \mu \mathrm{l}$ of essential oils was put on each disc and placed on agar. A witness disc (soaked in DMSO) was incubated under the same conditions to ensure that DMSO was devoid of antibacterial activity.

After incubation for $24 \mathrm{~h}$ in an oven at $37^{\circ} \mathrm{C}$, reading was done. The effect of essential oils on bacteria was estimated by the appearance of clear zones around the discs. The diameter of the halo of growth inhibition was measured and expressed in $\mathrm{mm}$ (including the diameter of the disc of $6 \mathrm{~mm}$ ).

\section{Determination of minimum inhibitory concentration (MIC)}

The minimum inhibitory concentration (MIC) is the smallest concentration of essential oil, in which no growth is visible compared to the control without extract. It was evaluated on twelve tested strains by disc diffusion test. We used the dilution method on solid medium (incorporation) (Billerbeck et al., 2002; Marino et al., 
2001).

Serial dilutions of essential oils were performed with DMSO for 2 h. Each dilution was incorporated into Mueller-Hinton medium, maintained, super cooled and poured into Petri dishes. The concentrations (in percent), of essential oils used are respectively: $1,0.5,0.25,0.01,0.125,0.06$ and 0.03 . Witness discs containing culture medium and only DMSO were also prepared.

Seeding was done as a deposit of bacterial suspension. After incubation at $35^{\circ} \mathrm{C}$ for six days, the growth was compared to the control.

\section{RESULTS AND DISCUSSION}

\section{Essential oil yield}

The yields of essential oils from the dry matter of Rosmarinus officinalis L., Laurus nobilis L. and Ocimum basilicum $\mathrm{L}$. were respectively $0.36,0.6$ and $0.71 \%$. These results are lower than those found in other regions of Algeria. The yield of Rosemary in Algiers found by Djeddi (2007) was $0.82 \%$ and Laurel in Tlemcen was 1.2\% (Haddouchi et al., 2009). These differences may result from the high moisture that characterizes the study's area; because it is known that maximum yields are obtained by dry weather. Concerning Basil, the yield obtained is normal because it develops in its natural habitat. Harvesting for the three plants was conducted during the vegetative stage, which has generated a relatively low yield (Bruneton, 1993).

\section{Antibiotic activity}

The antibacterial activity of the three essential oils and MIC values are grouped in Tables 1 and 2 .

All organisms are sensitive to the three oils except $P$. aeruginosa (Gram negative) which is more and more responsible for nosocomial infections. It has an intrinsic resistance to a wide range of antibiotics (April et al., 1992) and also to essential oils. This resistance is due to the impermeability of the wall of this bacterium (Djeddi et al., 2007; Dorman and Deans, 2000; Duke and Ayensu, 1985).

The essential oil of $L$. nobilis $L$. has demonstrated a strong activity on the majority of tested strains; the highest sensitivity was in Enterobacter sp. that has an inhibition diameter of $22.4 \mathrm{~mm}, 16.8 \mathrm{~mm}$ pure oil and 1/8 dilution. The most resistant strain was $P$. aeruginosa. These results are in concord with those of Dadalioglu and Evrendilek (2004). 1,8 cineole has a part in this activity since it has antimicrobial activity against several strains such as E. coli, P. aeruginosa and Staphylococcus aureus (Sivropoulou et al., 1997).

The synergy between terpenes (linalool), lactones, oxides (1, 8 cineole) and monoterpenes (camphene, alpha-pinene) gives to the essential oil of Laurel a good antibacterial activity. The MIC equals $2.72\left(10^{3}\right.$ micrograms/ml) exceptin E. faecalis ATCC 2921, S. aureus,
S. epidermidis, $P$. mirabilis and $S$. marcescens where it was $1.36\left(10^{3}\right.$ micrograms / $\left.\mathrm{ml}\right)$.

The essential oil of Rosmarinus officinalis also has an inhibitory power. The most sensitive strain is Shigella $s p$. (16.4 $\mathrm{mm}$ and $11.3 \mathrm{~mm}$ ). The MIC values are quite high, ranging from $3.43\left(10^{3} \mathrm{mg} / \mathrm{ml}\right)$ in E. faecalis ATCC 29212, S. Aureus, S. Epidermidis, E. coli ATCC 25922 Proteus mirabilis, $C$. freundii, S. marcescens and Shigella sp. to $6.85\left(10^{3} \mathrm{mg} / \mathrm{ml}\right)$ in Salmonella OMA 04 Enterobacter sp., A. baumannii and M.R.S.A ATCC31.

Our results are in agreement with those found by other authors such as Santoyo et al. (2005), Faleiro et al. (2003) and Gachka (2007) Fiorini et al. (1998) with respect to the resistance of Pseudomonas aeruginosa against this oil. Celikta (2007) found a moderate activity against E. faecalis and Proteus sp., however Jiang et al. (2011) obtained pronounced antibacterial activity.

Santoyo et al. (2005) and Graven (1992) attributed the antimicrobial properties of the essential oil of $R$. officinalis to the presence of a-pinene, 1,8-cineol, borneol and camphor. Even minor components have a significant contribution to the antibiotic activity (Wang et al., 2012).

Finally, with the essential oil of Ocimum basilicum, we found good inhibition zones. The most sensitive bacterial strain (Shigella sp.) presented an inhibition diameter ranging between $12.2 \mathrm{~mm}$ and $19.9 \mathrm{~mm}$.

Suppakul et al. (2003) reported, also, that Basil has good antimicrobial activity against a wide range of microorganisms. This activity is due in part to the presence of linalool (Koutsoudaki et al., 2005; Sartoratotto et al., 2004; Sokovic and Van Griensven, 2006; Suppakul et al., 2003). The MIC is equal to $9.5\left(10^{3}\right.$ $\mathrm{mg} / \mathrm{ml})$.

This study shows that Gram negative bacteria and Gram positive bacteria are both sensitive to the three essential oils.

It is known that Gram negative bacteria are more resistant to essential oils than Gram positive bacteria (Loäpez et al., 2005; Marino et al., 2001). This resistance is due to the nature of these group of cellular membranes of bacteria, because their external structures make them to have highly hydrophobic surfaces (Smith-Palmer et al., 1998). One important characteristic of essential oils and their components is their hydrophobicity, which allows them to partition the lipids of the bacterial cell membrane and mitochondria, disturbing the cell structures and making them more permeable (Sikkema et al., 1994).

Dorman and Deans (2000) indicate that the antimicrobial activity depends, not only, on the chemical composition of the essential oil, but also on lipophilic properties and power of functional groups or aqueous solubility. The mixture of compounds with different biochemical properties can improve the effectiveness of essential oils.

\section{Conclusion}

R. officinalis L., Laurus nobilis $\mathrm{L}$. and $O$. basilicum $\mathrm{L}$. are 
Table 1. Diameter of inhibition of essential oils against the bacterial strains $(\mathrm{mm})$.

\begin{tabular}{lcccccccccccc}
\hline \multirow{2}{*}{ Bacterial strain } & \multicolumn{4}{c}{ Laurus nobilis $\mathbf{L}$} & \multicolumn{4}{c}{ Rosmarinus officinalis $\mathbf{L}$} & \multicolumn{3}{c}{ Ocimum basilicum L } \\
\cline { 2 - 13 } & $\mathbf{B}$ & $\mathbf{1 / 2}$ & $\mathbf{1 / 4}$ & $\mathbf{1 / 8}$ & $\mathbf{B}$ & $\mathbf{1 / 2}$ & $\mathbf{1 / 4}$ & $\mathbf{1 / 8}$ & $\mathbf{B}$ & $\mathbf{1 / 2}$ & $\mathbf{1 / 4}$ & $\mathbf{1 / 8}$ \\
\hline E. faecalis ATCC 29212 & 12.5 & 11.3 & 11.3 & 11.1 & 11.3 & 10.3 & 12.5 & 9.6 & 9.4 & 9.4 & 11.2 & 11 \\
S. aureus ATCC 25923 & 15 & 9.1 & 8.3 & 7.4 & 14 & 12.4 & 8.7 & 8.4 & 9.75 & 9.7 & 9.5 & 9 \\
M.R.S.A ATCC 31 & 17.6 & 13.3 & 9.5 & 9.3 & 14.3 & 11.4 & 11.2 & 11 & 13.5 & 12.2 & 11.2 & 10.1 \\
S. aureus & 15.6 & 12.6 & 10.3 & 9.9 & 12.9 & 11.5 & 10.7 & 10.1 & 16 & 14.5 & 13.5 & 11.1 \\
S. epidermidis & 13.1 & 12 & 8.4 & 8.2 & 12.7 & 10.8 & 10.8 & 10.6 & 12.9 & 13.3 & 10.8 & 9.4 \\
Enterococcus avium & 12.8 & 12.1 & 10.7 & 10.3 & 10.4 & 8.2 & 8.1 & 8.1 & 10.2 & 10.1 & 9.4 & 9 \\
E. coli ATCC 25922 & 15.9 & 12.05 & 11.85 & 11.75 & 13.5 & 10.2 & 10.3 & 8.9 & 13.8 & 13.5 & 11 & 10.7 \\
Salmonella OMA 04 & 14 & 11.2 & 9.1 & $/$ & 11.5 & 9.8 & 9.8 & 9 & 12 & 9.8 & 9.2 & 8.9 \\
E. coli & 14.1 & 11.5 & 11.3 & 11 & 15.9 & 12.15 & 11.45 & 11 & 11.8 & 10.65 & 9.05 & 9 \\
Klebsiella oxytoca & 18 & 13.05 & 13.35 & 11.2 & 11 & 13.25 & 11.6 & 8.85 & 10 & 10.2 & 9.45 & 8.5 \\
Klebsiella pneumoniae & 17.6 & 15.6 & 13.7 & 13 & 12 & 11.6 & 11.3 & 10.8 & 18.8 & 17.2 & 13.3 & 10.1 \\
Proteus mirabilis & 16.25 & 12.6 & 11.45 & 10.7 & 11.1 & 9.2 & 12.9 & 9.8 & 12.6 & 11 & 13.1 & 11.3 \\
Enterobacter sp. & 22.4 & 22 & 20.4 & 16.8 & 12.7 & 11 & 9.4 & 9 & 13.6 & 13.1 & 13 & 11.3 \\
Citrobacter Freundii & 15 & 14.3 & 13.1 & 12.2 & 8.7 & 8.3 & 8.2 & 8.2 & 8.4 & 8.2 & 7.3 & 7 \\
P. aeruginosa & $/$ & $/$ & $/$ & $/$ & $/$ & $/$ & $/$ & $/$ & $/$ & $/$ & $/$ & $/$ \\
Acinetobacter baumannii & 16.8 & 16 & 14.1 & 12.5 & 9.2 & 9.1 & 9.1 & 9 & 14.5 & 11.3 & 9.5 & 9.4 \\
Serratia marceseus & 16.4 & 12.1 & 11.8 & 10.3 & 11.5 & 9.3 & 8.9 & 8.4 & 12 & 10.4 & 9.2 & 8.7 \\
Salmonella sp. & 17.1 & 14.1 & 11.5 & 10.8 & 12.5 & 11.6 & 11.4 & 10.4 & 15.3 & 10.8 & 10.7 & 10.1 \\
Shigella sp. & 21.1 & 19.3 & 18.4 & 16.3 & 16.4 & 14.3 & 12.6 & 11.3 & 19.9 & 13.7 & 12.4 & 12.2 \\
Providencia alcalifaciens & 16.2 & 14.4 & 13.2 & 11.1 & 11.4 & 10.5 & 10.2 & 10.1 & 16 & 12.1 & 11.3 & 9.8 \\
\hline
\end{tabular}

Table 2. Activity of essential oils incorporated in the solid medium (MIC).

\begin{tabular}{lccccccccccccc}
\hline Percentage & \multicolumn{3}{c}{$\mathbf{1} \%$} & \multicolumn{3}{c}{$\mathbf{0 . 5} \%$} & \multicolumn{3}{c}{$\mathbf{0 . 2 5} \%$} & \multicolumn{3}{c}{$\mathbf{0 . 1 2 5 \%}$} \\
\hline Extract (H.E) & B & R & L & B & R & L & B & R & L & B & R & L \\
\hline Concentration $\left(10^{3} \mathrm{\mu g} / \mathrm{ml}\right)$ & 9.5 & 6.85 & 5.4 & 4.95 & 3.43 & 2.72 & 2.47 & 1.71 & 1.36 & 1.23 & 0.85 & 0.68 \\
Gram positive & & & & & & & & & & & & \\
E. faecalis ATCC 29212 & - & - & - & - & - & - & + & + & - & + & + & + \\
M.R.S.A ATCC 31 & - & - & - & + & + & - & + & + & + & + & + & + \\
S. aureus & + & - & - & + & - & - & + & + & - & + & + & + \\
S. epidermidis & - & - & - & + & - & - & + & + & - & + & + & + \\
Gram negative & & & & & & & & & & & & \\
E. coli ATCC 25922 & - & - & - & + & - & - & + & + & + & + & + & + \\
Salmonella OMA 04 & - & - & + & + & + & + & + & + & + & + & + & + \\
Proteus mirabilis & - & - & + & + & - & + & + & + & + & + & + & + \\
Enterobacter sp. & + & - & - & + & + & - & + & + & - & + & + & + \\
Citrobacter Freundii & - & - & + & - & - & + & + & + & + & + & + & + \\
Acinetobacter baumannii & + & - & + & + & + & + & + & + & + & + & + & + \\
Serratia marcescens & - & - & - & - & - & - & - & + & + & + & + & + \\
Shigella sp. & - & - & - & - & - & - & - & + & - & + & + & + \\
\hline
\end{tabular}

-: No culture; +: presence of culture

widespread herbs in Algeria. The samples used have been harvested in the National Park of El Kala where Basil and Rosemary are cultivated and Laurel is spontaneous. The essential oils from leaves of Rosemary, Laurel and Basil were extracted by hydro-distillation using Likens Nickerson apparatus for $2 \mathrm{~h}$.
The aim of this study was to evaluate the three essential oils against 20 bacterial strains. For 12 strains we have determined the minimum inhibitory concentration (MIC). The three oils showed good antibacterial activity against both Gram negative and Gram positive bacteria. Laurel oil is the most efficient, Shigella sp. has 
the highest sensitivity to the three oils and Pseudomonas aeruginosa is the most resistant to them. Among the three oils, Laurel gives the lowest MIC against $E$. faecalis ATCC 29212, Enterobacter sp., Shigella sp., S. aureus and S. Epermidis (0.25\%).

\section{REFERENCES}

Aouadi H (1989). La Végétation de l'Algérie Nord-orientale: Histoire des Influences Anthropiques, et Cartographie à 1/200 000. Ph.D. Thesis. Univ. Joseph Fourier, Grenoble 1: Sciences, Technologie, Médecine.

Appendino G, Tagliapietra S, Nano GM, Cisero M (1992). A sesquiterpene alcohol from the fruits of Laurus nobilis. Phytochemistry 31:2537-2538.

Atik Bekkara F, Bousmaha L, Taleb Bendiab SA, Boti JB, Casanova J (2007). Composition chimique de l'huile essentielle de Rosmarinus officinalis L. poussant à l'état spontané et cultivé de la région de Tlemcen. Biologie Santé 7(1):6-11.

Bais HP, Walker TS, Schweizer HP, Vivanco JM (2002). Root specific elicitation and antimicrobial activity of Rosamarinic acid in rainy root cultures of sweet basil (Ocimum basilicum L.). Plant Physiol. Biol. Chem. 40:983-995.

Barla A, Topçu G, Öksüz S, Tümen G, Kingston DGI (2007). Identification of cytotoxic sesquiterpenes from Laurus nobilis L. Food Chem. 104:1478-1484.

Billerbeck VG, Roques C, Vaniére P, Marquier P (2002). Activité antibactérienne et antifongique des produits à base d'huiles essentielles. Hygiénes X-n`3:248-251.

Bruneton J (1993). Pharmacognosy. Phytochemistry. Plants médicinales. 2ème edition TEC \& DOC-Lavoisier.Paris. 406-417.

Celiktas OY, Kocabas EEH, Bedir E, Sukan FV, Ozek T, Baser KHC (2007). Antimicrobial activities of methanol extracts and essential oils of Rosmarinus officinalis, depending on location and seasonal variations. Food Chemistry 100:553-559.

Chiej R (1984). Encyclopaedia of Medicinal Plants. MacDonald. ISBN 0356-10541-5, Little, Brown.

Dadalioglu I, Evrendilek GA (2004). Chemical composition and antibacterial effect of essential oils of Turkish Oregano (Origanum minutifolium), Bay Laurel (Laurus nobilis), Spanish Levander (Lavandula stoechas L.), and Fennel (Foeniculum vulgare), on common Foodborne pathogens. J. Agric. Food Chem. 52:8255-8260.

Dall'Acqua S, Viola G, Giorgetti M, Loi MC, Innocenti G (2006). Two new sesquiterpene lactones from the leaves of Laurus nobilis. Chem. Pharm. Bull. 54:1187-1189.

Davis $J$ (1994). Inactivation of antibiotics and the dissemination of resistance genes. Science 264:375 - 382.

De Belair G (1990). Structure, fonctionnement et perspective de gestion de quatre ecocomplexes lacustres et marécageux (EI Kala Est Algérien). Ph.D. Thesis. Univ. Sci. Tech. Languedoc. Montpellier.

De Marino S, Borbone N, Zollo F, Lanaro A, Di Meglio P, Iorizzi M (2004). Megastigmane and phenolic components from Laurus nobilis L. leaves and their inhibitory effects on nitric oxide production. J. Agric. Food Chem. 52:7525-7531.

Djeddi S, Bouchenah N, Settar I, Skaltsa HD (2007). Composition and antimicrobial activity of the essential oil of Rosmarinus officinalis from Algeria. Chem. Natural Comp. 43(4):487-490.

Dorman HJD, Deans SG (2000). Antimicrobial agents from plants:antibacterial activity of plant volatile oils. J. Appl. Microbiol. 88:308-316.

Duke JA, Ayensu ES (1985). Medicinal Plants of China. Reference Publications. Inc. :ISBN 0-917256-20-4. Reference Publications, Algonac, MI (USA).

Faleiro ML, Miguel MG, Ladeiro F, Venâncio F, Tavares R, Brito JC, Figueiredo AC, Barroso JG, Pedro LG (2003). Antimicrobial activity of essential oils isolated from Protuguese endemic species of Thymus. Lett. Appl. Microbiol. 36:35-40.

Fiorini C, David B, Fouraste I, Vercauteren J (1998). Acylated kaempferol glycosides from Laurus nobilis leaves. Phytochemistry $47: 821-824$
Fraga BM (2003). Natural sesquiterpenoids. Nat. Prod. Rep. 20:392413.

Gachkar L, Yadegari D, Rezaei MB, Taghizadeh M, Astaneh SA, Rasooli I (2007).Chemical and biological characteristics of Cuminum cyminum and Rosmarinus officinalis L. essential oils. Food Chemistry 102:898-904.

Garcia R, Alves ES, Santos MP, Viégas Aquije GMF, Fernandes AAR, Santos RB, Ventura JA, Fernandes PMB (2008). Antimicrobial activity and potential use of monoterpenes as tropical fruits preservatives. Braz. J. Microbiol. 39:163-168.

Graven EH, Deans SG, Svoboda K, Mavi S, Gundidza MG (1992). Antimicrobial and antioxidant properties of the essential oil of Artemisia afra. Flav Fragra J. 7:121-123.

Grayer RJ, Bryan SE, Veitch NC, Goldstone FJ, Paton A, Wollenweber E (1996). External flavones in sweet basil Ocimum basilicum, and related taxa. Phytochemistry 43:1041-1047.

Haddouchi F, Lazouni HA, Meziane A, Benmansour A (2009). Etude physicochimique et microbiologique de l'huile essentielle de Thymus fontanesii Boiss \& Reut. Afrique SCIENCE 05(2):246 - 259.

Jiang $\mathrm{Y}, \mathrm{Wu} \mathrm{N}$, Fu YJ, Wang W, Luo M, Zhao CH, Zu YG, Lio XL (2011). Chemical composition and antimicrobial activity of the essential oil of Rosemary. Environ. Toxicol. Pharmacol. 1417:6.

Juliani HR, Simon JE (2002). Antioxidant Activity of Basil. Trends in new crops and new uses. J. Janick and A. Whipkey (eds.). ASHS Press, Alexandria, VA. pp. 575-579.

Kalamba D, Kunicka A (2003). Antibacterial and antifungal properties of essential oils. Curr. Med. Chem. 10:813-829.

Kivcak B, Mert T (2002). Preliminary evaluation of cytotoxic properties of Laurus nobilis L. leaf extracts. Fitoterapia 73:242-243.

Koutsoudaki C, Krsek M, Rodger A (2005). Chemical composition and antibacterial activity of the essential oil and the gum of Pistacia lentiscus Var. J. Agric. Food Chem. 53:7681-7685.

Lee J, Scagel CF (2010). Chicoric acid levels in commercial basil (Ocimum basilicum) and Echinacea purpurea products. J. Functional Foods 2:77-84

Loäpez P, Saänchez C, Batlle R, Neriän C (2005). Solid- and VaporPhase Antimicrobial Activities of Six Essential Oils: Susceptibility of Selected Foodborne Bacterial and Fungal Strains. J. Agric. Food Chem. 53(17):6939-6946.

Lust J (1983). The Herb Book. Bantam books:ISBN 0-553-23827-2, New York.

Marino M, Bersani C, Comi G (2001). Impedence measurements to study the antimicrobial activity of essential oils from Lamiaceae and Compositeae. Int. J. Food Microbiol. 67:187-195.

NCCLS (National Committee for Clinical Laboratory Standards) (2002). Methods for dilution antimicrobial susceptibility tests of bacteria that grow aerobically. Approved Standard M100-S12. Wayne. PA NCCLS

Novák M (1985). A monoterpene alcohol from Laurus nobilis. Phytochemistry 24:858.

Park HJ, Jung WT, Basnet P, Kadota S, Namba T (1996). Syringin 4-Obglucoside, a new phenylpropanoid glycoside, and costunolide, a nitric oxide synthase inhibitor, from the stem bark of Magnolia sieboldii. J. Nat. Prod. 59:1128-1130.

Quezel P, Santa S (1963). New flora of Algeria and southern desert regions. Edition. Natl. Centre Sci. Res. 2:276.

Santoyo S, Cavero S, Jaime L, Ibanez E, Senorans FJ, Reglero G (2005). Chemical composition and antimicrobial activity of Rosmarinus officinalis $L$. essential oil obtained via supercritical fluid extraction. J. Food Protect. 68 (4):790-795.

Sartoratotto A, Machado ALM, Delarmelina C, Figueira GM, Duarte MCT, Rehder VLG (2004). Composition and antimicrobial activity of essential oils from aromatic plants used in Brazil. Braz. J. Microbiol. $35: 275-280$.

Service RF (1995). Antibiotics that resist resistance. Science 270:724727.

Siddiqui BS, Aslam H, Ali ST, Begum S, Khatoon N (2007). Two new triterpenoids and a steroidal glycoside from the aerial parts of Ocimum basilicum. Chem. Pharm. Bull. 55:516-519.

Sikkema J, De Bont JAM, Poolman B (1994). Interactions of cyclic hydrocarbons with biological membranes. J. Biol. Chem. 269:8022 8028. 
Sivropoulou A, Nikolaou C, Papanikolaou E, Kokkini S, Lanaras T, Arsenakis M (1997). Antimicrobial, cytotoxic, and antiviral activities of Salvia fruticosa essential oil. J. Agric. Food Chem. 45:3197-3201.

Smith-Palmer A, Stewart J, Fyfe L (1998). Antimicrobial properties of plant essential oils and essences against five important food bornepathogens. Lett. Appl. Microbiol. 26:118-122.

Sokovic M, Van Griensven LJ (2006). Antimicrobial activity of essential oils and their components against the three major pathogens of the cultivated button mushroom, Agaricus bisporus. Eur. J. Plant Pathol. 116:211-224.

Suppakul P, Miltz J, Sonneveld K, Bigger SW (2003). Antimicrobial properties of basil and its possible application in food packing. J. Agric. Food Chem. 51:3197-3207.
Trujano-Gonzalez ME, Pena El, Martinez AL, Moreno J, Guevara-Fefer $P$, Déciga-Campos M, Lopez-Munoz FJ (2007). Evaluation of the antinociceptive effect of Rosmarinus officinalis $L$. using three different experimental models in rodents. J. Ethnopharmacol. $111: 476-482$.

Wang W, Li N, Luo M, Zu Y, Efferth T. (2012). Antibacterial activity and anticancer activity of Rosmarinus officinalis L. essential oil Compared to that of its main component. Molecules. 17:2704-271. 